\title{
Physical parameters of Fluvisols on flooded and non-flooded terraces
}

\author{
Milena Kercheva ${ }^{1 *}$, Zofia Sokołowska², Mieczysław Hajnos ${ }^{2}$, Kamil Skic $^{2}$, and Toma Shishkov ${ }^{1}$ \\ ${ }^{1}$ Department of Soil Physics, Institute of Soil Science, Agrotechnology and Plant Protection "N. Poushkarov", Shosse Bankya 7, \\ Sofia 1080, Bulgaria \\ ${ }^{2}$ Institute of Agrophysics, Polish Academy of Science, Doświadczalna 4, 20-290 Lublin, Poland
}

Received March 17, 2016; accepted December 12, 2016

\begin{abstract}
A b s t r a c t. The heterogeneity of soil physical properties of Fluvisols, lack of large pristine areas, and different moisture regimes on non-flooded and flooded terraces impede the possibility to find a soil profile which can serve as a baseline for estimating the impact of natural or anthropogenic factors on soil evolution. The aim of this study is to compare the pore size distribution of pristine Fluvisols on flooded and non-flooded terraces using the method of the soil water retention curve, mercury intrusion porosimetry, nitrogen adsorption isotherms, and water vapour sorption. The pore size distribution of humic horizons of pristine Fluvisols on the non-flooded terrace differs from pore size distribution of Fluvisols on the flooded terrace. The peaks of textural and structural pores are higher in the humic horizons under more humid conditions. The structural characteristics of subsoil horizons depend on soil texture and evolution stage. The peaks of textural pores at about $1 \mu \mathrm{m}$ diminish with lowering of the soil organic content. Structureless horizons are characterized by uni-modal pore size distribution. Although the content of structural pores of the subsoil horizons of Fluvisols on the non-flooded terrace is low, these pores are represented by biopores, as the coefficient of filtration is moderately high. The difference between non-flooded and flooded profiles is well expressed by the available water storage, volume and mean radius of pores, obtained by mercury intrusion porosimetry and water desorption, which are higher in the surface horizons of frequently flooded Fluvisols.

K e y w o r d s: soil porous system, Fluvisols, soil water retention, mercury intrusion porosimetry, nitrogen adsorption, water vapour desorption
\end{abstract}

\section{INTRODUCTION}

Fluvisols are young soils that have been directly exposed to hydrological variations and to intensive agricultural exploitation for centuries. Traditionally, the Bulgarian systematics (Koinov, 1980) recognizes a much larger group

*Corresponding author e-mail: mkercheva@abv.bg of soils formed on alluvial terraces and valleys that may develop in the absence of continued flooding and deposition of recent alluvium under conditions of irregular river flow. The flooding occurrences in many European countries, including Bulgaria, have increased over the last years (eg 2005, 2014), which affect soil properties on large areas and provoke interest in monitoring of these soils.

Fluvisols are characterized by high vertical and horizontal heterogeneity, which is explained with the varying characteristics of alluvial sediments, regime of deposition, age of formation (distance to the river), and land use. The agronomic significance of Fluvisols provokes long-standing interest in determining and mapping of soil physical and chemical properties for designing a hydromelioration system. Geostatistical analysis and interpretation of spatial variability of the physical properties of Fluvisols are often applied for the purposes of site-specific farming (Iqbal et al., 2005; Orfánus et al., 2016) and for predicting water and salute transport in soil (Botros et al., 2009). The effect on organic carbon along various hydrological gradients associated with flood recurrence was investigated by SaintLaurent et al. (2016).

Besides variability, the information for the baseline values of physical characteristics of soils is essential for monitoring of soil status and evolution. Total porosity, infiltration rate, bulk density, and soil organic matter content are among the characteristics commonly used for estimation of land change effects. Gajić (2013) found that the conversion of forest Fluvisols to grassland and to arable lands has led to a significant decrease in total porosity, infiltration rate, and soil organic matter in the top $20 \mathrm{~cm}$ of soil.

(C) 2017 Institute of Agrophysics, Polish Academy of Sciences 
Soil structure, represented by solid components (aggregates) and a pore system, is considered as a main indicator of soil physical status and is related to a variety of ecological functions (Dexter, 2004; Dilkova, 2014; Horn et al., 1994; Józefaciuk, 2009; Kutílek and Jendele, 2008). Baseline values of different categories of pores and pore size distribution are used as criteria for assessing the effects of management practices (Hajnos et al., 2006; Lipiec et al., 2012). Comparative studies on the hydrophysical properties and pore structure of soils from different climatic zones (Witkowska-Walczak et al., 2015) and soils with different genesis (Dilkova, 2014; Sławiński et al., 2011) are important for understanding and predicting the ongoing changes of the soil hydrological functions. Data on nitrogen and water vapour adsorption in soils are used to evaluate the surface area of adsorbents, surface roughness or irregularity, and energetic parameters (Sokołowska and Bańka, 2009; Sokołowska et al., 2002). This information is useful for describing transport processes, water retention and release of chemicals, aggregate stability, and shrinking and swelling of soil.

The aim of this study is to compare the pore size distribution, water retention and transmission properties of pristine Fluvisols on flooded and non-flooded terraces using different measurement techniques.

\section{MATERIAL AND METHODS}

The studied Fluvisols are situated along the Maritsa River on the territory of Tsalapitsa village, Plovdiv region, Southern Bulgaria (Fig. 1). The relief of the region is flat. Parent materials are deposits of different origin. Three soil profiles were morphologically described and sampled: under a grass association (profile 1: $42^{\circ} 10.85^{\circ} \mathrm{N}$, $24^{\circ} 32.57^{\prime} \mathrm{E}$, Altitude $192 \mathrm{~m}$ a.s.l.) and under acacia trees (profile 2: $42^{\circ} 10.74^{\prime} \mathrm{N}, 24^{\circ} 32.55^{\prime} \mathrm{E}$, Altitude $188 \mathrm{~m}$ a.s.l.) on the first non-flooded river terrace and under a grass association on the first flooded terrace (profile $3: 42^{\circ} 09.22^{\prime} \mathrm{N}$, 24⒊39'E, Altitude $182 \mathrm{~m}$ a.s.1.). The soil was classified as Haplic Fluvisol (IUSS Working Group WRSB, 2006). The level of ground water table is about 4-6 $\mathrm{m}$ under profiles 1 and 2 , and $0.7 \mathrm{~m}$ under profile 3 .

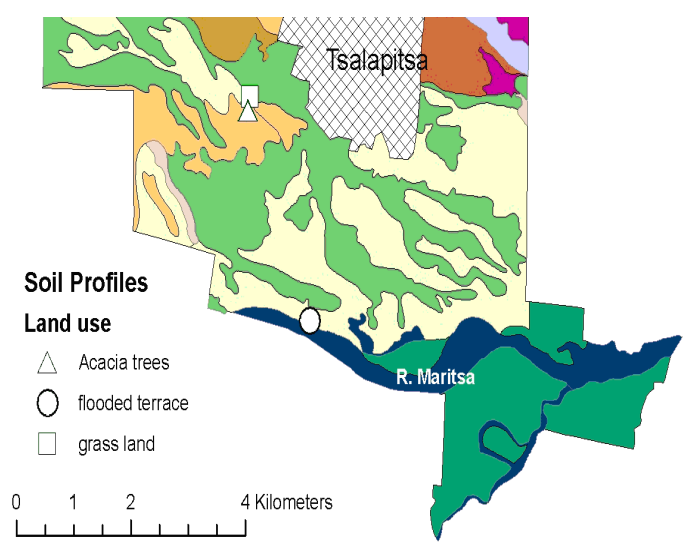

Fig. 1. Locations of soil profiles on soil map (1:10000).
The Thracian plain is referred to as a transitional region of the European moderate-continental climate zone. Mean air temperature is $0.1^{\circ} \mathrm{C}$ in the coldest month (January) and $23.4^{\circ} \mathrm{C}$ in the hottest month (July). The mean annual precipitation sum is $512 \mathrm{~mm}$. The difference between precipitation and evapotranspiration is $-290 \mathrm{~mm}$ on average for the June-August period. The duration of the period with air temperature above $10^{\circ} \mathrm{C}$ is 209 days and the temperature sum is $3795^{\circ} \mathrm{C}$ for this period.

The morphological description of soil profiles was done according to the FAO guidelines (FAO, 2006). The soil profiles were sampled starting from the surface layer $0-5 \mathrm{~cm}$, following the soil genetic horizons. An average 'disturbed' sample from each sampling depth was formed by gentle breaking and mixing the excavated fresh soil by hands into aggregates finer than about $15 \mathrm{~mm}$. Vertically oriented soil cores were sampled in 4 replicates in $100 \mathrm{~cm}^{3}$ metal cylinders for determination of bulk density and water retention (ISO 11274:1998).

Soil texture fractions were determined after chemical dispersion of $10 \mathrm{~g}$ air-dry soil sample $(<2 \mathrm{~mm})$ with $25 \mathrm{~cm}^{3}$ of $0.4 \mathrm{~N}$ sodium pyrophosphate $\left(\mathrm{Na}_{4} \mathrm{P}_{2} \mathrm{O}_{7}\right)$ without removal of organic matter and carbonates from the soil sample. Four sand fractions $(2-1,1-0.5,0.5-0.25,0.25-0.10 \mathrm{~mm})$ were determined by sieving, and the fifth sand fraction $0.10-0.05 \mathrm{~mm}$ was calculated. Particle fractions less than $0.05,0.02,0.01$, and $0.002 \mathrm{~mm}$ were determined with the conventional pipette method. Particle-size distribution and textural classes were determined according to USDA (Soil Survey Division Staff, 1993).

Particle density analysis was carried out in water with $100 \mathrm{~cm}^{3}$ pycnometers.

The total soil organic carbon (SOC) content was determined with modified Tjurin method [dichromate digestion at $125^{\circ} \mathrm{C}, 45 \mathrm{~min}$., in the presence of $\mathrm{Ag}_{2} \mathrm{SO}_{4}$ and $\left(\mathrm{NH}_{4}\right)_{2}$. $\mathrm{SO}_{4} \mathrm{FeSO}_{4} 6 \mathrm{H}_{2} \mathrm{O}$ titration, phenyl anthranilyc acid as an indicator (Filcheva and Tsadilas, 2002; Kononova, 1966)]. The SOC content was classified according to Filcheva (Filcheva, 2014).

Four different methods were used for characterization of the soil porous system: the method of the soil water retention curve, mercury intrusion porosimetry (MIP), nitrogen adsorption isotherms, and water vapour desorption isotherms.

Soil water retention at suction less than $30 \mathrm{kPa}$ was determined using the undisturbed soil cores $\left(100 \mathrm{~cm}^{3}\right)$ with a suction plate method similar to those proposed in ISO 11274: 1998. The wetting of the soil samples at $0.25 \mathrm{kPa}$ in a sand bath lasted more than 20 days. The drainage of the wetted samples at $1,5,10$, and $30 \mathrm{kPa}(\mathrm{pF} 1.0,1.7,2.0$, and 2.5) was done by suction type apparatus (Shot filters G5 with diameters of pores 1.0-1.6 $\mu \mathrm{m}$ ). Equilibrium for each suction value was established for 5-7 days. Soil water retention at suction $1500 \mathrm{kPa}(\mathrm{pF}$ 4.2) was determined using fine $(<2 \mathrm{~mm})$ earth samples with pressure membrane 
apparatus. Total porosity $(\mathrm{Pt})$ was calculated using the measured bulk density and particle density. The volume of air-filled pores at given suction $P$ was calculated as the difference between total porosity $\mathrm{Pt}$ and the measured volume of water content $(\theta)$ retained at this suction for each replicate $(n=4)$. The average values and standard deviations of the obtained data were calculated. The effective pore radius $r$ corresponding to the applied suction $(P)$ was calculated with Jurin formula:

$$
P=\frac{2 \gamma_{\mathrm{H}_{2} \mathrm{O}}}{r},
$$

where: $\gamma_{\mathrm{H}_{2} \mathrm{O}}$ is the surface tension of water $\left(0.0729 \mathrm{~J} \mathrm{~m}^{-2}\right)$ and $P(\mathrm{~Pa})$.

An Autopore IV 9500 (Micrometrics INC, USA) mercury porosimeter was used to determine the pore size distribution (PSD). Before intruding mercury in step-wise pressure increments in the range from 0.036 to $413 \mathrm{MPa}$, the undisturbed soil aggregates with open pore structures were oven-dried at $105^{\circ} \mathrm{C}$ and degassed in a vacuum under pressure $6.67 \mathrm{~Pa}$ at a temperature of $20^{\circ} \mathrm{C}$. Pore size distribution (PSD) - was determined using the Washburn equation (1921):

$$
P=\frac{2 \gamma_{H g} \cos \theta}{r},
$$

where: $P$ is the external pressure $(\mathrm{Pa})$ applied in the vacuum chamber, $\gamma_{\mathrm{Hg}}$ is the surface tension of mercury (485 J $\left.\mathrm{m}^{-2}\right), \theta$ is the contact angle of mercury $\left(130^{\circ}\right)$, and $r$ is the pore radius of pore aperture $(\mathrm{m})$ for a cylindrical pore. This approach allows determination of pore radii ranging from 0.0015 to $47 \mu \mathrm{m}$. This wide range allows detection of diverse soil pore classes along the PSD curve. The average pore radius (2V/A) was obtained by assuming that all pores are right cylinders, thus when the volume $\left(\mathrm{V}=\pi \mathrm{r}^{2} \mathrm{~L}\right)$ is divided by the pore area $(\mathrm{A}=2 \pi \mathrm{rL})$, the average pore radius $(r)$ is equal to $2 \mathrm{~V} / \mathrm{A}$.

The method of nitrogen adsorption isotherms was used to determine pores of an equivalent radius $0.1-0.001 \mu \mathrm{m}$ (Greeg and Sing, 1982; Ościk, 1982). The isotherms were measured using a Sorptomatic (model SO 1990, Fisons Instruments) at the temperature of liquid nitrogen $\left(-195.82^{\circ} \mathrm{C}\right)$ in the range of relative pressures of nitrogen from $p / p_{o}=0.004$ to $p / p_{o}=0.997$. The measurements were done on soil samples of 1 to $3 \mathrm{~g}$, depending on the specific surface area, in three replicates. Computer software (attached to the instrument) was used to determine the volume of the pores.

Pores of an equivalent radius $0.05-0.001 \mu \mathrm{m}$ were determined by water vapour desorption isotherms (Naono and Hakuman, 1993). The soil was air-dried and sieved, and aggregates less than $2 \mathrm{~mm}$ were used. The measurements were done on $2 \mathrm{~g}$ samples in three replicates. The isotherms were measured using the vacuum chamber method as described above; however, sulphuric acid at stepwise increasing concentrations was used (decrease of $p / p_{o}=$ relative vapour pressure; $p$ is the equilibrium vapour pressure, and $p_{o}$ is the saturated vapour pressure at temperature T). We assumed that the micropore radius, $R_{\text {mic }}$, in the capillary condensation process is related to the vapour pressure $p$ by the Kelvin equation for the hemispherical meniscus with zero water/solid contact angle and that the condensation in micropores occurs above $p / p_{o}=0.35$ (below this value, surface adsorption processes dominate) (Ościk, 1982). Thus the total micropore volume ( $V_{\text {mic }}$, total) was taken as the volume of adsorbed water at the maximum $p$ / $p_{o}$ value minus the volume of adsorbed water at $p / p_{o}=0.35$.

The results were plotted in two graphical forms. In the first form, the cumulative pore volume was plotted against a logarithmically spaced abscissa, and in the second form the differential PSD based on the logarithmic differentiation $\mathrm{dV} / \mathrm{d}(\lg (\mathrm{r}))$ was calculated. Both forms of presentation have the same unit $\left(\mathrm{cm}^{3} \mathrm{~g}^{-1}\right)$ and therefore can be directly compared.

Saturated hydraulic conductivity was determined in laboratory conditions using the method of diminishing water head and was classified according to Soil Survey Staff (1971).

\section{RESULTS AND DISCUSSION}

The studied Fluvisols on non-flooded and flooded terraces differ significantly according to the thickness of the $\mathrm{A}+\mathrm{AC}$ horizons and particle size distribution (Table 1). The thicknesses of the surface humic horizons for profiles 1, 2, and 3 are 73, 82, and $23 \mathrm{~cm}$, respectively, and the textures are Loam, Sandy Clay Loam, and Silt Loam. The distributions of soil texture within the soil profile are also different. In profile 1 (under a grass association), the soil texture becomes finer with depth, resembling an illuvial horizon. The soil profile 2 (under Acacia trees) has homogeneous texture in depth - Sandy Clay Loam. Soil profile 3 situated on the flooded terrace, near the river, is characterized by coarser texture of the $\mathrm{C}$ horizon with alternation of texture class in depth typical for alluvial soils. The low contents of clay $(<15 \%)$ and soil organic matter $(<0.2 \%)$ explain the structureless $\mathrm{C}$ horizons of profile 3 .

The soil organic carbon (SOC) content in surface layers varies from medium $(1.20 \%$ in the $0-5 \mathrm{~cm}$ soil layer of profile 1$)$, high (2.45\% in the $0-6 \mathrm{~cm}$ layer of profile 3$)$, to very high $(11.87 \%$ in the $0-2 \mathrm{~cm}$ soil layer of profile 2$)$. The highest content of SOC in the surface layer under forest is usually explained with the high level of soil organic matter (SOM) input (Gajić, 2013). The average value of SOC for the $0-20 \mathrm{~cm}$ soil layer in profile 3 is $1.72 \%$ and it is comparable to the results for frequent flood zones ( $\mathrm{SOC}=1.74 \%$ ) obtained by Saint-Laurent et al. (2016) for the region of southern Québec, Canada. The lower average values of SOC for this layer in the non-flooded terrace $(2.00 \%$ for profile 2 and $0.69 \%$ for profile 1) than those reported by 
M. KERCHEVA et al.

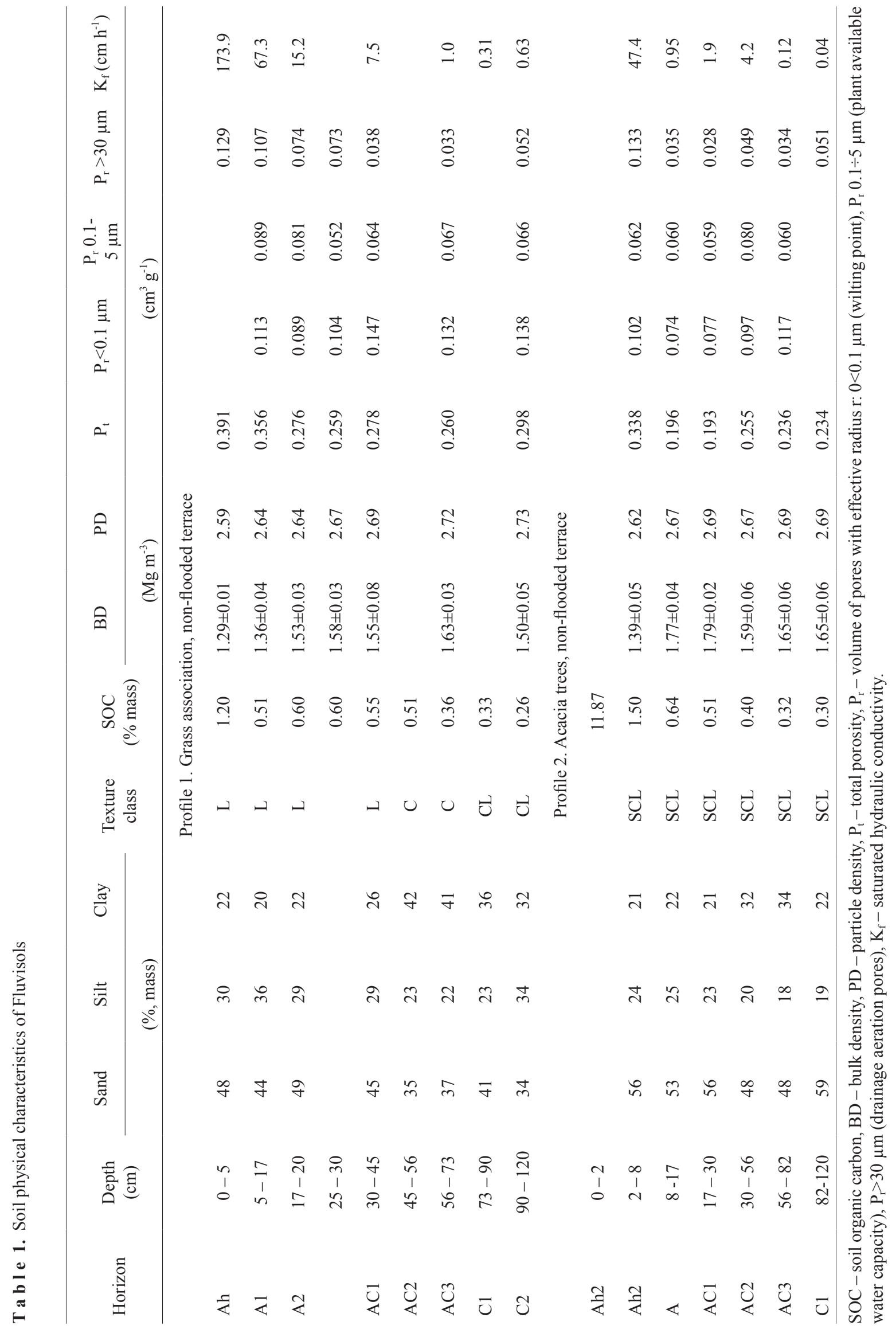




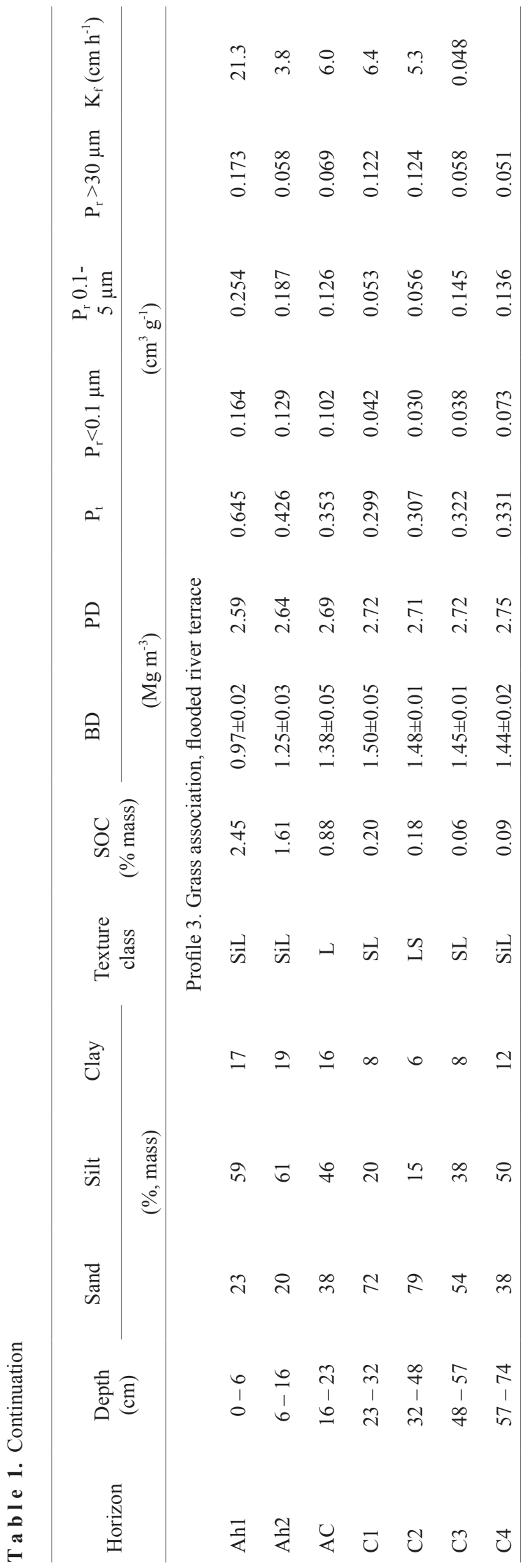

Saint-Laurent et al. (2016) (3.34\% for moderately flooded and $3.54 \%$ for non-flooded zones) can be explained with the warmer and dryer climatic conditions in the region of Tsalapitsa.

The profile distributions of bulk density (BD) and particle density (PD) are inversely related to the distribution of the SOC content. The effect of low organic content on high values of bulk density is best pronounced in soil under Acacia trees, which is Sandy Clay Loam throughout the whole soil profile (profile 2) (Table 1).

The pore size distribution data obtained with four methods are presented graphically as cumulative and differential curves for chosen humic (Figs 2a, 3a) and subsoil horizons (Figs 2b, 3b). The similarity in the pore size distribution in the humic horizons of the non-flooded profiles (1 and 2) is well manifested by cumulative and differential curves obtained with the MIP (Figs 2a, 3a), nitrogen adsorption, and water desorption methods. The cumulative curve obtained with these methods for the flooded profile 3 is positioned above the ones for profiles 1 and 2 . The cumulative curves of water retention (WRC) data match at some points the MIP curves for the humic horizons of profile 1 and 3 , but they differ significantly for profile 2 as well as for subsoil horizons. The reason is the use of non-disturbed soil samples for WRC determination, while the other methods use soil aggregates less than $2 \mathrm{~mm}$. Hajnos et al. (2006) explained the greater concentration of pore volume with pore radius 7.5 to $0.1 \mu \mathrm{m}$ obtained from the water retention curve than from the mercury intrusion porosimetry method with the different measurement procedures. The main characteristics of porous space obtained by MIP are presented in Table 2.

All surface humic horizons of the profiles are characterized by good water transmission properties (Table 1, Figs 2a, 3a). They consist of sufficient quantities of pores with equivalent radii $>30 \mu \mathrm{m}$, determined by WRC: 0.129 , 0.133 , and $0.173 \mathrm{~cm}^{3} \mathrm{~g}^{-1}$, respectively, for profiles 1,2 , and 3 (Table 1, Fig. 2a). The filtration of the surface layer is very fast $\left(173.9 \mathrm{~cm} \mathrm{~h}^{-1}\right)$ in profile 1 and fast in profile $2(47.4 \mathrm{~cm}$ $\left.\mathrm{h}^{-1}\right)$ and profile $3\left(21.3 \mathrm{~cm} \mathrm{~h}^{-1}\right)$ (Table 1).

Deterioration of the soil structure in the subsoil layers is manifested by a blocky structure or lack of structure, small $\left(<0.10 \mathrm{~cm}^{3} \mathrm{~g}^{-1}\right)$ content of aeration pores with drainage functions, and lowering of the filtration rate to moderately high and moderately low. The compaction of the subsoil horizons is caused by different factors. In the case of profile 1, the diminishing of the volume of large pores in the $\mathrm{AC} 3$ horizon can be explained with the increased content of fine particles. In the case of profile 2, this is provoked by low content of organic matter and coarse soil texture. In the case of profile 3 , the compaction of the $\mathrm{C} 4$ horizon is due to slaking of the structureless horizon above the groundwater table. Although the content of structural pores of the subsoil horizons of Fluvisols on the non-flooded terrace is 
a

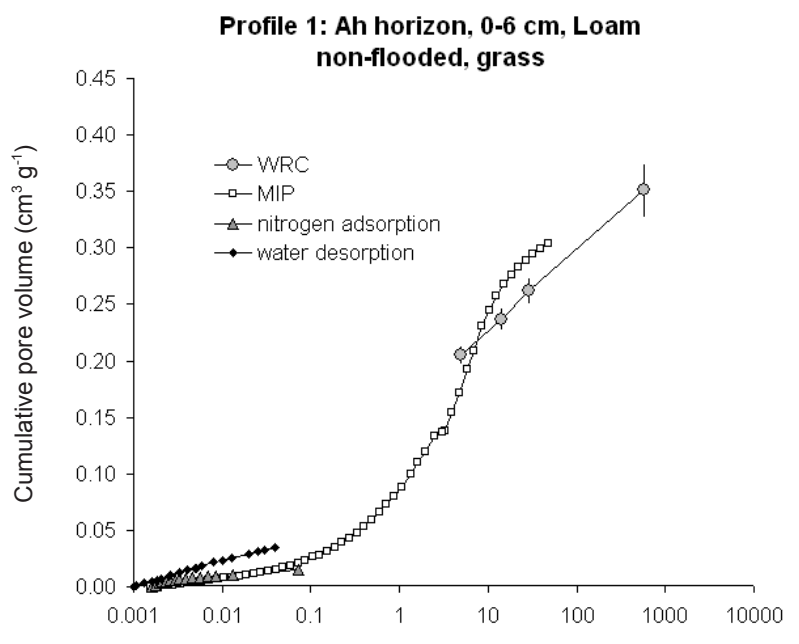

Profile 2: Ah2 horizon, $2.8 \mathrm{~cm}$, Sandy Clay Loam

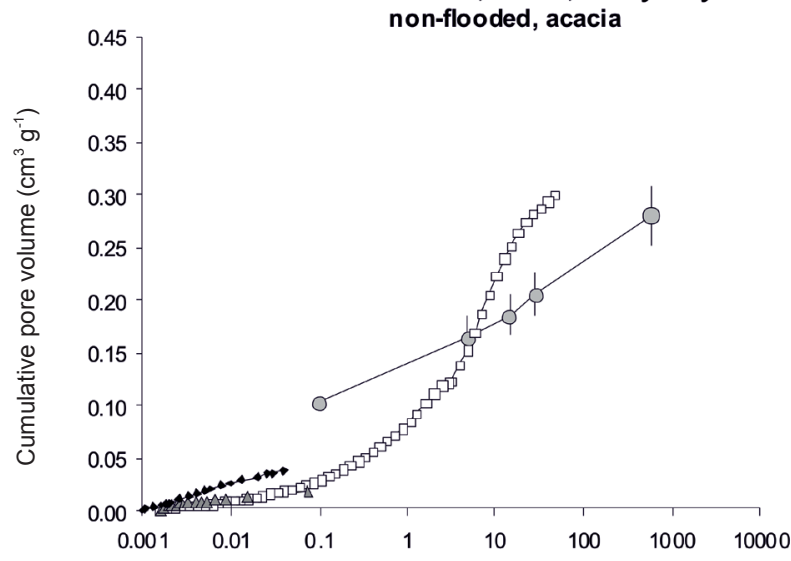

Profile 3: Ah2 horizon, 6-16 cm, Silt Loam

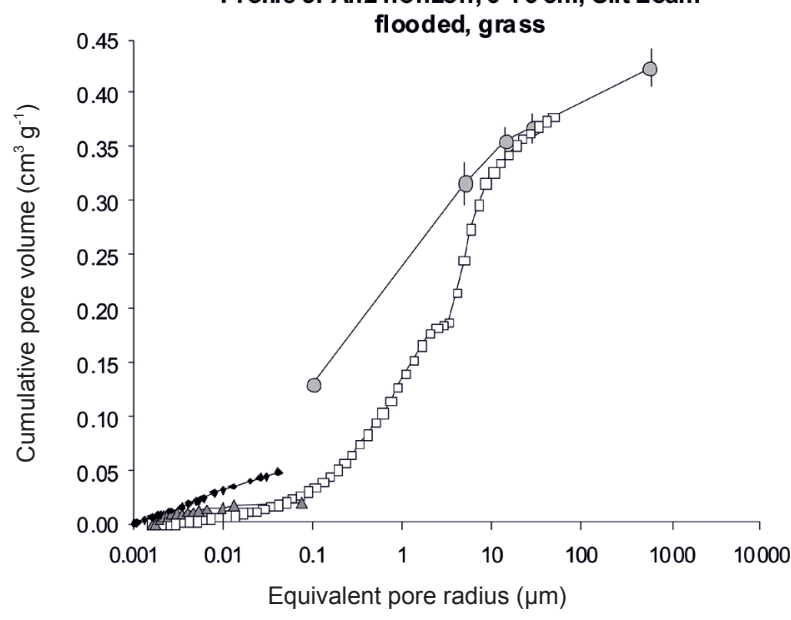

b
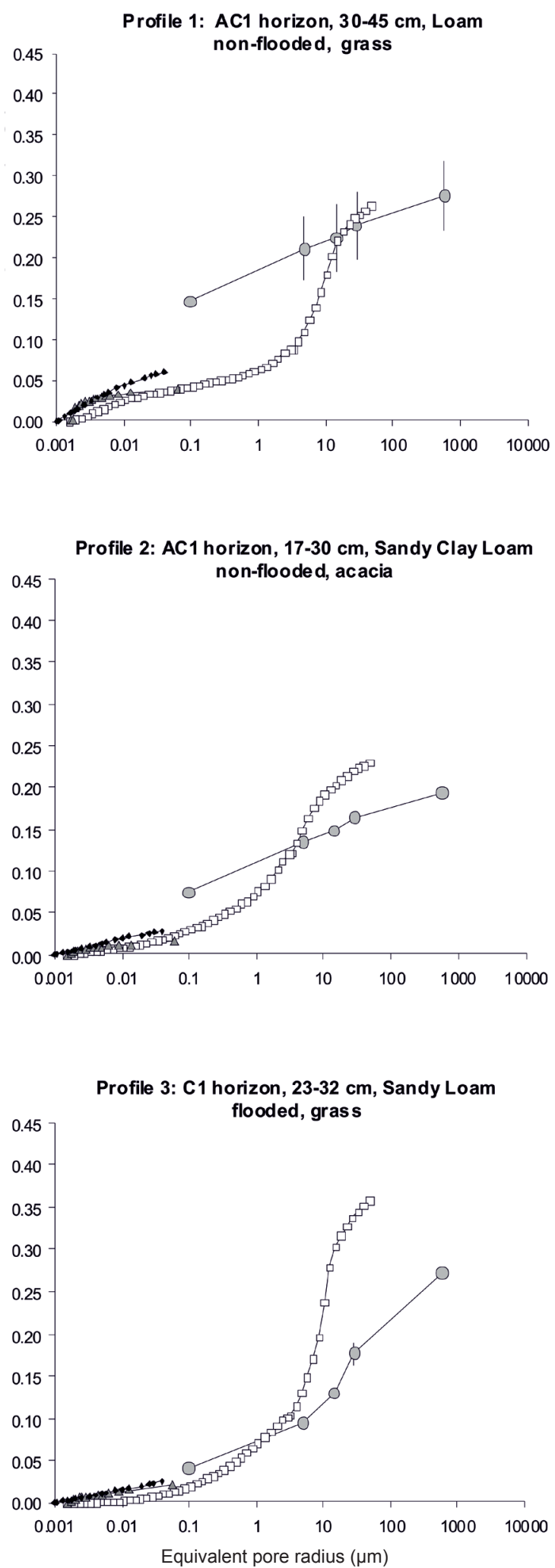

Fig. 2. Cumulative curve of pore volume $v s$. equivalent pore radius for water retention curve (WRC), mercury intrusion porosimetry (MIP), nitrogen adsorption isotherm and water desorption isotherm: a - humic horizons (Ah), b - subsoil horizons. 

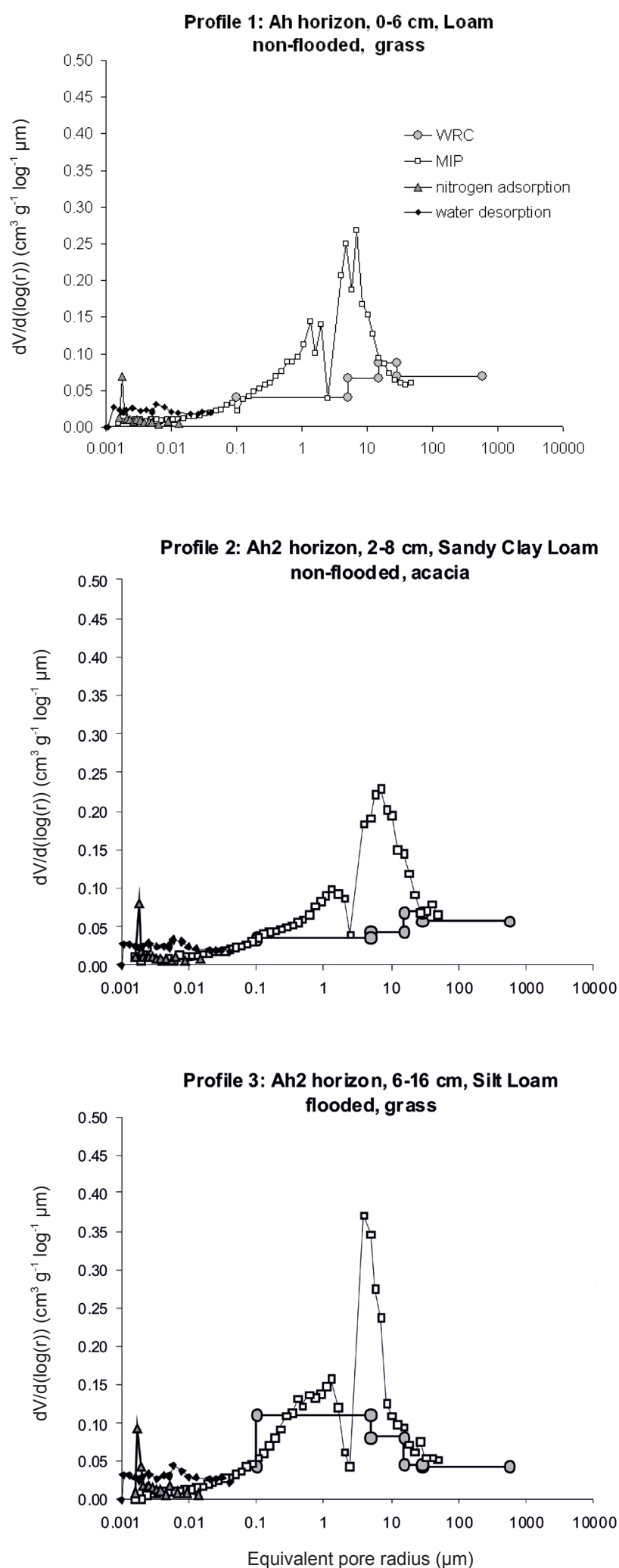

b

Profile 1: AC1 horizon, $30-45 \mathrm{~cm}$, Loam non-flooded, grass
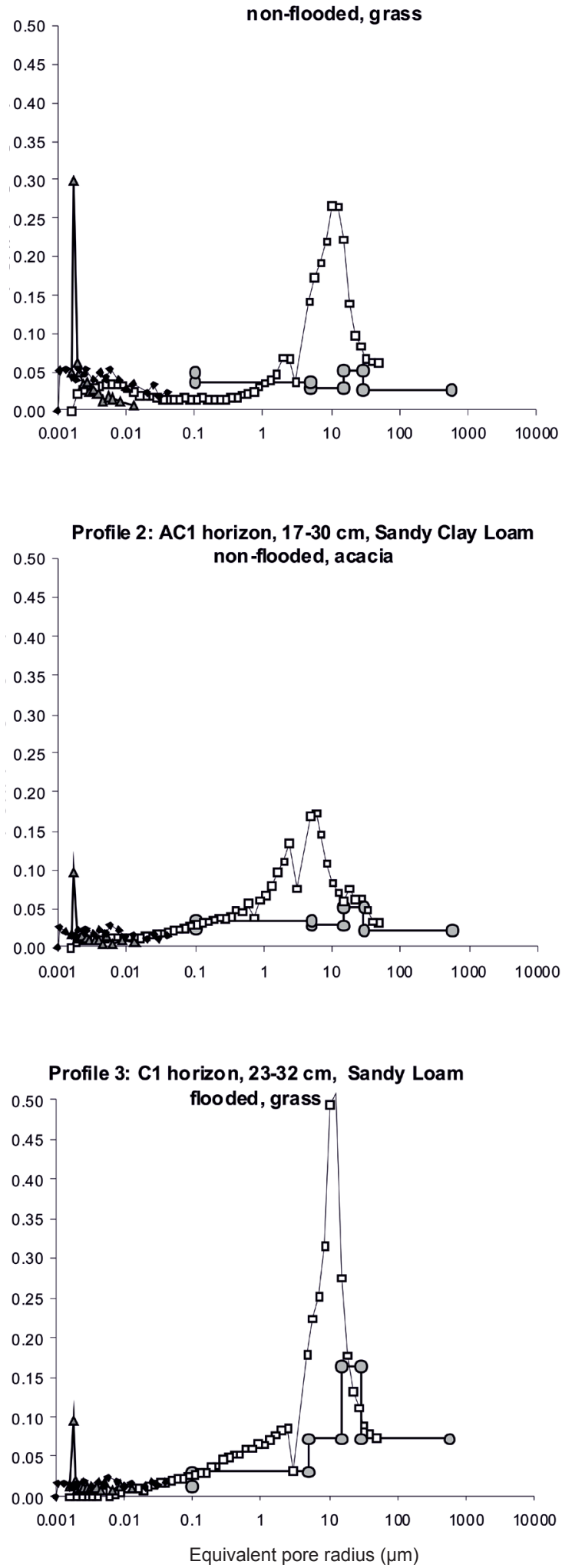

Fig. 3. Differential curve of pore volume $v s$. equivalent pore radius for water retention curve (WRC), mercury intrusion porosimetry (MIP), nitrogen adsorption isotherm and water desorption isotherm: a - humic horizons (Ah), b - subsoil horizons. 
T a b l e 2. Characteristics of porous space obtained by MIP

\begin{tabular}{|c|c|c|c|c|c|}
\hline Horizon & $\begin{array}{l}\text { Depth } \\
(\mathrm{cm})\end{array}$ & $\begin{array}{l}\text { Total intrusion } \\
\text { volume }\left(\mathrm{cm}^{3} \mathrm{~g}^{-1}\right)\end{array}$ & $\begin{array}{l}\text { Total pore area } \\
\qquad\left(\mathrm{m}^{2} \mathrm{~g}^{-1}\right)\end{array}$ & $\begin{array}{c}\text { Average pore radius } \\
(2 \mathrm{~V} / \mathrm{A}) \\
(\mu \mathrm{m})\end{array}$ & $\begin{array}{c}\text { Porosity } \\
(\%)\end{array}$ \\
\hline \multicolumn{6}{|c|}{ Profile 1. Grass association, non-flooded river terrace } \\
\hline $\mathrm{Ah}$ & $0-5$ & 0.343 & 5.58 & 0.123 & 44.4 \\
\hline A1 & $5-17$ & 0.415 & 6.80 & 0.122 & 48.9 \\
\hline \multirow[t]{2}{*}{$\mathrm{A} 2$} & $17-20$ & 0.300 & 6.49 & 0.093 & 41.2 \\
\hline & $25-30$ & 0.284 & 8.43 & 0.067 & 39.9 \\
\hline $\mathrm{AC} 1$ & $30-45$ & 0.298 & 15.53 & 0.038 & 41.4 \\
\hline $\mathrm{AC} 2$ & $45-56$ & 0.290 & 17.40 & 0.033 & 40.1 \\
\hline $\mathrm{AC} 3$ & $56-73$ & 0.319 & 11.35 & 0.056 & 43.0 \\
\hline $\mathrm{C} 2$ & $73-90$ & 0.280 & 10.31 & 0.054 & 39.5 \\
\hline \multicolumn{6}{|c|}{ Profile 2. Acacia trees, non-flooded river terrace } \\
\hline Ah1 & $0-2$ & 1.246 & 8.35 & 0.298 & 69.7 \\
\hline Ah2 & $2-8$ & 0.339 & 6.99 & 0.097 & 42.8 \\
\hline A & $8-17$ & 0.267 & 7.65 & 0.070 & 38.6 \\
\hline $\mathrm{AC} 1$ & $17-30$ & 0.253 & 6.62 & 0.076 & 37.3 \\
\hline $\mathrm{AC} 2$ & $30-56$ & 0.228 & 9.89 & 0.046 & 35.5 \\
\hline $\mathrm{AC} 3$ & $56-82$ & 0.283 & 15.15 & 0.037 & 40.6 \\
\hline $\mathrm{C} 1$ & $82-120$ & 0.291 & 10.46 & 0.056 & 40.6 \\
\hline \multicolumn{6}{|c|}{ Profile 3. Grass association, flooded river terrace } \\
\hline Ah1 & $0-6$ & 0.532 & 5.09 & 0.209 & 56.3 \\
\hline Ah2 & $6-16$ & 0.410 & 4.97 & 0.165 & 47.9 \\
\hline $\mathrm{AC}$ & $16-23$ & 0.399 & 4.67 & 0.171 & 49.0 \\
\hline $\mathrm{C} 1$ & $23-32$ & 0.398 & 2.16 & 0.368 & 49.7 \\
\hline $\mathrm{C} 2$ & $32-48$ & 0.356 & 0.56 & 1.281 & 47.7 \\
\hline $\mathrm{C} 3$ & $48-57$ & 0.327 & 0.81 & 0.811 & 45.3 \\
\hline $\mathrm{C} 4$ & $57-74$ & 0.439 & 6.35 & 0.138 & 53.0 \\
\hline
\end{tabular}

low $\left(0.03-0.06 \mathrm{~cm}^{3} \mathrm{~g}^{-1}\right)$, these pores are most probably represented by biopores (roots), as the coefficient of filtration is moderately high ( 0.36 to $\left.3.6 \mathrm{~cm} \mathrm{~h}^{-1}\right)$.

The volume of pores holding water available for plants (equivalent pore radius from $0.1 \mu \mathrm{m}$ till $5 \mu \mathrm{m}$ ), evaluated by WRC, is small $\left(0.06 \div 0.09 \mathrm{~cm}^{3} \mathrm{~g}^{-1}\right)$ in Fluvisols on the non-flooded terrace (profiles 1 and 2) and high in most soil layers of profile 3 on the flooded terrace $\left(0.13 \div 0.25 \mathrm{~cm}^{3}\right.$ $\mathrm{g}^{-1}$ ), with the exception of the $\mathrm{C} 1$ and $\mathrm{C} 2$ horizons, where PAWC is also small $\left(0.05 \div 0.06 \mathrm{~cm}^{3} \mathrm{~g}^{-1}\right)$.

The peaks at the equivalent pore radius $0.0017 \mu \mathrm{m}$, determined by nitrogen adsorption, are similar for the selected Ah horizons (0.06-0.09 $\left.\mathrm{cm}^{3} \mathrm{~g}^{-1}\right)$, while they differ significantly for the selected subsoil horizons - 0.21 ,
0.11 , and $0.08 \mathrm{~cm}^{3} \mathrm{~g}^{-1}$, respectively for profile 1 (AC3, clay), profile 2 (A, Sandy Clay Loam), and profile 3 (C4, Silt Loam).

The differential curves obtained by MIP reveal two peaks separated by the minima occurring at $r=2.4 \mu \mathrm{m}$ in the humic horizons and at $\mathrm{r}=3.0 \mu \mathrm{m}$ in the subsoil horizons. These radii correspond to the lowest values separating the structural and textural domains obtained for loams and silt loams ( $\mathrm{r}=50 \mu \mathrm{m}$ to $2.4 \mu \mathrm{m})$ by Kutílek and Jendele (2008) and are less than the value $(\mathrm{r}=4 \mu \mathrm{m})$ for silt loam Eutric Fluvisol obtained by Lipiec et al. (2007), commented also in Sławiński et al. (2011). The first peak established by MIP for aggregates $<2 \mathrm{~mm}$ is detected at $r \approx 1 \mu \mathrm{m}$ and diminishes with lowering of the soil organic content. Sławiński et al. (2011) reported that the first maximum 
T a b I e 3. Surface $(0-25 \mathrm{~cm})$ and sub-surface $(25-50 \mathrm{~cm})$ characteristics of non-flooded (profile 1, profile 2) and flooded (profile 3 ) Fluvisols

\begin{tabular}{|c|c|c|c|c|c|c|}
\hline \multirow{3}{*}{ Parameter } & \multicolumn{4}{|c|}{ Non-flooded } & \multirow{2}{*}{\multicolumn{2}{|c|}{$\begin{array}{l}\text { Flooded } \\
\text { Profile } 3 \\
\end{array}$}} \\
\hline & \multicolumn{2}{|c|}{ Profile 1, grass } & \multicolumn{2}{|c|}{ Profile 2, acacia } & & \\
\hline & $0-25 \mathrm{~cm}$ & $25-50 \mathrm{~cm}$ & $0-25 \mathrm{~cm}$ & $25-50 \mathrm{~cm}$ & $0-25 \mathrm{~cm}$ & $25-50 \mathrm{~cm}$ \\
\hline SOC stock $\left(\mathrm{kg} \mathrm{m}^{-2}\right)$ & 2.34 & 2.12 & 3.84 & 1.72 & 4.34 & 0.65 \\
\hline Clay content $(\%)$ & 21 & 27 & 21 & 30 & 17 & 7 \\
\hline $\begin{array}{l}\text { Volume of micro pores }-0.1 \text { to } \\
0.001 \mu \mathrm{m} \text { (nitrogen ads.) }\left(\mathrm{cm}^{3} \mathrm{~g}^{-1}\right)\end{array}$ & 0.02 & 0.03 & 0.02 & 0.03 & 0.02 & 0.02 \\
\hline $\begin{array}{l}\text { Volume of micro pores }-0.05 \text { to } \\
0.001 \mu \mathrm{m} \text { (water des.) }\left(\mathrm{cm}^{3} \mathrm{~g}^{-1}\right)\end{array}$ & 0.04 & 0.07 & 0.04 & 0.05 & 0.06 & 0.02 \\
\hline $\begin{array}{l}\text { Volume of pores }-47 \text { to } 0.0015 \mu \mathrm{m} \\
\text { (MIP) }\left(\mathrm{cm}^{3} \mathrm{~g}^{-1}\right)\end{array}$ & 0.36 & 0.29 & 0.36 & 0.23 & 0.44 & 0.37 \\
\hline Total porosity $\left(100 \mathrm{~cm}^{3}\right.$ rings $)$ & 0.34 & 0.27 & 0.36 & 0.24 & 0.45 & 0.31 \\
\hline $\begin{array}{l}\text { Mean micro pore radius }(\mu \mathrm{m}) \\
\text { (nitrogen ads.) }\end{array}$ & 0.0018 & 0.0019 & 0.0019 & 0.0019 & 0.0019 & 0.0019 \\
\hline $\begin{array}{l}\text { Mean micro pore radius }(\mu \mathrm{m}) \\
\text { (water des.) }\end{array}$ & 0.008 & 0.007 & 0.008 & 0.008 & 0.009 & 0.009 \\
\hline Mean pore radius $(\mu \mathrm{m})(\mathrm{MIP})$ & 0.113 & 0.042 & 0.097 & 0.052 & 0.193 & 0.988 \\
\hline Available water storage (mm) & 30 & 24 & 29 & 31 & 52 & 23 \\
\hline
\end{tabular}

in the bi-modal pore distribution of aggregates less than $1 \mathrm{~mm}$ in Eutric Fluvisol occurred at $\mathrm{r}=0.7 \mu \mathrm{m}$. The second MIP peaks in the humic horizons in our study are found between $r=4$ to $7 \mu \mathrm{m}$ under the grass association and between $\mathrm{r}=4-15 \mu \mathrm{m}$ under the forest. Structureless subhorizons are characterized by uni-modal PSD according to the MIP data (Fig. 3b).

The content of organic stocks and characteristics of pores, averaged for surface $0-25 \mathrm{~cm}$ and subsurface $25-50 \mathrm{~cm}$ soil layers are presented in Table 3. The organic carbon stocks in $0-25 \mathrm{~cm}$ soil layer are $2.3,3.8$, and $4.3 \mathrm{~kg} \mathrm{~m}^{-2}$ in profiles 1, 2, and 3, correspondingly (Table 3 ). The stocks in the $25-50 \mathrm{~cm}$ soil layer are in inverse order $2.1,1.7$, and $0.7 \mathrm{~kg} \mathrm{~m}^{-2}$ in profiles 1,2 , and 3 , correspondingly. It can be concluded that the fluvial outwash and more humid conditions near the river create better conditions for accumulation of organic carbon in the surface layer of the youngest soil profile 3 under the grass association.

The difference between non-flooded and flooded profiles is well expressed by the available water storage, volume and mean radius of pores obtained by MIP, and water desorption, which are higher in the surface horizons of frequently flooded Fluvisols. There is no difference in the average volumes and mean radius of pores obtained by nitrogen adsorption, which are closely related to soil texture.

\section{CONCLUSIONS}

1. The difference between non-flooded and flooded profiles is well expressed by the available water storage, volume and mean radius of pores obtained by MIP, and water desorption, which are higher in the surface horizons of frequently flooded Fluvisols.

2. The pore size distribution of humic horizons of pristine Fluvisols on the non-flooded terrace differs from pore size distribution of Fluvisols on the flooded terrace. The peaks of textural and structural pores are higher in the humic horizons under more humid conditions.

3. The textural peaks at about $1 \mu \mathrm{m}$ pore radius diminish with lowering of the soil organic content. Structureless subhorizons are characterized by uni-modal pore size distribution according to mercury intrusion porosimetry data. Although the content of structural pores of the subsoil horizons of Fluvisols on the non-flooded terrace is low, these pores are most probably represented by biopores, as the coefficient of filtration is moderately high.

Conflict of interest: The Authors do not declare conflict of interest. 


\section{REFERENCES}

Botros F.E., Harter T., Onsoy Y.S., Tuli A., Hopmans J.W., 2009. Spatial Variability of hydraulic properties and sediment characteristcs in a deep alluvial unsaturated zone. Vadose Zone J., 8, 276-289, doi:10.2136/vzj2008.0087

Dexter A.R., 2004. Soil physical quality. Part I. Theory, effects of soil texture, density, and organic matter, and effects on root growth. Geoderma, 120, 201-214.

Dilkova R., 2014. Structure, physical properties and aeration of soils in Bulgaria (in Bulgarian). PSSE, Sofia, Bulgaria.

FAO, 2006. Guidelines for soil description. Rome: Food and Agriculture Organization of the United Nations.

Filcheva E., 2014. Humus development, soil organic matter content and carbon stocks in different soil groups (in Bulgarian). In: Soil Organic Matter and Fertility of Soils in Bulgaria (Ed. Sl. Krastanov), BHSS, Sofia, Bulgaria.

Filcheva E. and Tsadilas C., 2002. Influence of cliniptilolite and compost on soil properties. Commun. Soil Sci. Plant Analysis, 33(3-4), 595-607.

Gajić B., 2013. Physical properties and organic matter of Fluvisols under forest, grassland, and 100 years of conventional tillage. Geoderma, 200-201, 114-119.

Greeg S.J. and Sing K.S.W., 1982. Adsorption, Surface Area and Porosity. Acad. Press, New York, USA.

Hajnos M., Lipiec J., Świeboda R., Sokołowska Z., and Witkowska-Walczak B., 2006. Complete characterization of pore size distribution of tilled and orchard soil using water retention curve, mercury porosimetry, nitrogen adsorption, and water desorption methods. Geoderma, 135, 307-314.

Horn R., Taubner H., Wuttke M., and Baumgartl T., 1994. Soil physical properties related to soil structure. Soil Till. Res., 30, 187-216.

Iqbal J., Thomasson J.A., Jenkins J.N., Owens Ph.R., and Whisler Fr.D., 2005. Spatial variability analysis of soil physical properties of alluvial soils. Soil Sci. Soc. Am. J., 69, 1-14.

ISO 11274:1998 named: 'Soil quality - Determination of the water retention characteristics - Laboratory methods'.

IUSS Working Group WRSB, 2006. World reference base for soil resources 2006. A framework for international classification, correlation and communication. Worlds Soil Resources Reports No 103. FAO, Rome.

Józefaciuk G., 2009. Effect of the size of aggregates on pore characteristics of minerals measured by mercury intrusion and water-vapor desorption techniques. Clays Clay Minerals, 57(5), 586-601.
Koinov V., Giurov G., and Kolcheva B., 1980. Soil science (in Bulgarian). Textbook. Zemizdat. Sofia, Bulgaria.

Kononova M., 1966. Soil Organic Matter. Pergammon Press, Inc., M. V., 544p.

Kutílek M. and Jendele L., 2008. The structural porosity in soil hydraulic functions - a review. Soil Water Res., 3 (Special Issue 1), S7-S20.

Lipiec J., Hajnos M., and Świeboda R., 2012. Estimating effects of compaction on pore size distribution of soil aggregates by mercury porosimeter. Geoderma, 179-180, 20-27.

Lipiec J., Walczak R., Witkowska-Walczak B., Nosalewicz A., Slowińska-Jurkiewicz A., and Sławiński C., 2007. The effect of aggregate size on water retention and pore structure of silt loam soils of different genesis. Soil Till. Res., 97, 239-246.

Naono H. and Hakuman M., 1993. Analysis of porous texture by means of water vapor desorption isotherm with particular attention to lower limit of hysteresis loop. J. Colloid Interface Sci., 158, 19-26.

Orfánus T., Stojkovová D., Nagy V., and Németh T., 2016. Variability of soil water content controlled by evapotranspiration and groundwater-root zone interaction. Archives of Agronomy and Soil Science, doi: 10.1080/03650340.2016. 1155700

Ościk J., 1982. Adsorption. Ellis Horwood, Chichester.

Saint-Laurent D., Paradis R., Drouin A., and Gervais-Beaulac V., 2016. Impacts of floods on organic carbon concentrations in alluvial soils along hydrological gradients using a Digital Elevation Model (DEM). Water, 8, 208. www. mdpi.com/journal/water doi:10.3390/w8050208

Sławiński C., Witkowska-Walczak B., Lipiec J., and Nosalewicz A., 2011. Effect of aggregate size on water movement in soils. Int. Agrophys., 25, 53-58.

Soil Survey Division Staff, 1993. Soil survey manual. Soil Conservation Service. U.S. Department of Agriculture, Handbook 18.

Sokołowska Z. and Bańka P., 2009. Effect of surface cations on strongly bound water in alluvial soils (in Polish). Acta Agrophysica, 13(3), 781-792

Sokołowska Z., Borówko M., Reszko-Zygmunt J., and Sokołowski S., 2002. Adsorption of nitrogen and water vapor by alluvial soils. Geoderma,107, 33-54.

Washburn E.W., 1921. The dynamics of capillary flow. Phys. Rev., 273-283.

Witkowska-Walczak B., Bartmiński P., and Slawiński C., 2015. Hydrophysical characteristics of selected soils from arctic and temperate zones. Int. Agrophys., 29, 525-531. 